\title{
Productivity and profitability of alternative steer growth paths resulting from accessing high-quality forage systems in the subtropics of northern Australia: a modelling approach
}

\author{
M. K. Bowen ${ }^{\mathrm{A}, \mathrm{C}}$ and F. Chudleigh ${ }^{\mathrm{B}}$ \\ A Department of Agriculture and Fisheries, Rockhampton, PO Box 6014, Red Hill, Qld 4701, Australia. \\ ${ }^{B}$ Department of Agriculture and Fisheries, PO Box 102, Toowoomba, Qld 4350, Australia. \\ ${ }^{\mathrm{C}}$ Corresponding author. Email: maree.bowen@daf.qld.gov.au
}

\begin{abstract}
Beef producers have to determine the best allocation of a limited resource of high-quality forage. This analysis assessed the most profitable way of incorporating high-quality forages into the whole-of-life steer growth path on forage systems in central Queensland, using property-level, regionally relevant herd models that determine whole-of-business productivity and profitability over a 30-year investment period. Twenty-two growth paths (liveweight change over time) from weaning to marketing were investigated for steers grazing buffel grass (Cenchrus ciliaris) pastures with and without access to leucaena-grass pastures (Leucaena leucocephala spp. glabrata + perennial, tropical grass (C4) species) or forage oats (Avena sativa) for varying intervals throughout their growth path. The production, economic and financial effect of each growth path was assessed by comparison to a base scenario that produced finished, slaughter steers $(605 \mathrm{~kg})$ from buffel grass pastures. The relative profitability of marketing steers at feedlot entry (feed-on) weight (474 kg) instead of slaughter weights was also assessed. The growth paths were applied within two beef enterprises, namely (1) steer turnover and (2) breeding and finishing. For both enterprises, grazing steers on leucaena-grass pastures from weaning until they achieved feedlot entry weight $(474 \mathrm{~kg})$ was substantially more profitable than any other growth path. Compared with the base scenario, this optimal growth path improved profitability by $121 \%$ and $37 \%$ for the steer turnover and the breeding and finishing enterprises respectively. The purchase of additional breeders for the latter enterprise was required to optimise utilisation of the leucaena-grass pastures immediately. Incorporating leucaena-grass pastures at any steer age improved the profitability of the steer turnover enterprise (AU\$7368-AU\$106 508 extra profit/annum), and similarly for the breeding and finishing enterprise (AU\$1754-AU\$31383 extra profit/annum) except for two scenarios where leucaena-grass pastures were provided to older steers targeted at the feed-on market (AU\$4816 and AU\$23 886 less profit/annum). However, incorporation of leucaena-grass into steer growth paths also resulted in increased peak deficit levels and financial risk to the business compared with buffel grass-only production systems, with payback periods for the most profitable growth path of 8 and 14 years for the steer turnover and the breeding and finishing enterprise respectively. All growth paths that incorporated forage oats and leucaena-grass resulted in lower economic and financial performance than did comparable growth paths that incorporated leucaena-grass only. Furthermore, incorporating oats into buffel grass-only growth paths always reduced the enterprise profitability. There was no relationship, across scenarios within an enterprise, between change in profit and the number of extra weaners produced or the amount of extra beef produced per hectare.
\end{abstract}

Additional keywords: beef cattle, dryland cropping, farm management economics, leucaena, oats, tropical forages, tropical pastures.

Received 15 May 2018, accepted 28 November 2018, published online 18 December 2018

\section{Introduction}

The Fitzroy Natural Resource Management (NRM) Region of central Queensland is an important beef producing area of Australia, producing $\sim 12 \%$ of Australia's gross value of cattle in 2016-2017 from $\sim 12.2$ million ha of grazing land (DNRM 2017b; ABS 2018). The Fitzroy NRM region falls largely within the Brigalow Belt bioregion, with $\sim 42 \%$ of the land area used for grazing in the Fitzroy having arable soils capable of supporting sown forages suitable for beef cattle finishing (slaughter) or backgrounding (preparing for feedlot entry; DNRM 2010, 2017b). Although the Brigalow Belt bioregion has been regarded as a highly productive agricultural area due to its inherent soil fertility and moderate rainfall environment, pasture and beef cattle productivity have appreciably declined since widespread tree clearing during the 1960s-1980s for pasture establishment (Thornton and Elledge 2013; DNRM 2017a). This is primarily due to a 'run-down' or a decline in available nitrogen $(\mathrm{N})$ in the soil with an increasing age of the pasture stand since tree clearing (Peck et al. 2011, 2017). Furthermore, this decline in productivity of the largely buffel 
grass (Cenchrus ciliaris) pastures has been exacerbated in some cases by sustained heavy grazing pressure causing a decline in land condition (Beutel et al. 2014), and by invasion by the less productive pasture species, Indian couch (Bothriochloa pertusa; Spiegel 2016) and the increasing but poorly understood phenomenon of pasture dieback (Buck 2017).

Establishment of adapted legumes into the existing grass pastures has been identified as the best long-term option to increase both the productivity and returns from run-down, sown grass pastures due to their ability to biologically fix atmospheric N (Peck et al. 2015, 2017). Of the commercially available perennial legumes adapted to central Queensland, leucaena (Leucaena leucocephala spp. glabrata) has been identified as the most productive and profitable, increasing beef production per hectare by $\sim 2.5$ times and doubling gross margin per hectare, compared with perennial grass pastures (Bowen et al. 2018). The area planted to leucaena in the Fitzroy NRM region is currently estimated to be $\sim 106000$ ha (Corbet et al. 2016). Assessments of suitable soil and climatic conditions indicate that there is considerable scope to expand plantings within this region as well as across Queensland (Beutel et al. 2018), with Peck et al. (2011) estimating that leucaena has been sown to only $2.5 \%$ of the area in Queensland to which it is adapted.

Although perennial legumes, especially leucaena, have been identified as the most profitable high-quality forage option in central Queensland, annual forage cropping is common despite the marginal contribution to business profit (Bowen et al. 2015a, $2015 b$ ). Studies of commercial beef production systems in central Queensland showed oats (Avena sativa) to result in the greatest gross margin per hectare of the commonly applied annual forage crop options in central Queensland (Bowen et al. 2018).

Beef producers will generally have only a limited area of suitable soil on any particular property for sowing to highquality forages. Also, additional capital and skills are required to effectively establish and utilise high-quality forages. Hence, for implementation of any high-quality forage system to be profitable, producers need to be well informed and targeted in how they increase business inputs. In particular, producers need to make choices about how best to allocate high-quality forages among different age groups of steers in their herd to optimise profit. Producers need to consider options such as the steer age and length of grazing period on high-quality forage as well as the target market. The effect of such alternative management strategies is best assessed using property-level, regionally relevant herd models that determine the marginal improvement in productivity and profitability (Malcolm 2000).

The objective of the present study was to conduct a scientific and economic analysis of alternative steer growth paths on perennial buffel grass pasture in central Queensland, with or without access to (1) leucaena-grass pastures or (2) forage oats provided at various intervals in their growth path from weaning to marketing. These two, high-quality, forage interventions were considered as examples of sown perennial legume-grass pastures and annual forage crops respectively. Aspects of this research have been reported in conference proceedings (Bowen and Chudleigh 2018).

\section{Materials and methods}

\section{Approach}

The implications of alternative steer growth paths on the productivity and profitability of a beef enterprise were investigated for representative beef cattle enterprises in central Queensland, by using a case-study method to allow detailed analysis of the farm business (Yin 1994). Steer growth paths (liveweight change over time) for steers from weaning to marketing were developed for each of 22 scenarios from interrogation of existing datasets and from the expert opinion of experienced Department of Agriculture and Fisheries, Queensland staff, as described in more detail below. The economic and financial effect of each of these growth paths was assessed by comparison to a base production system of turning off finished steers from buffel grass pastures, as this is a common production system in the region and has historically been the most profitable (Bowen et al. 2015a). The growth paths were applied within two beef enterprise types, one being a steer turnover enterprise and the second a breeding and finishing beef enterprise. These enterprises and their characteristics were selected to be broadly representative of typical enterprise types and property sizes in the region and were not intended to provide a direct comparison for a similar number of steers carried (Bowen et al. 2015a, 2015b; Barbi et al. 2016).

Property-level, regionally relevant herd models were used to determine whole-of-business productivity and profitability over a 30-year investment period. This analysis interval was selected to match the minimum expected economic life of leucaena and, thus, to allow appropriate comparison of all forage combinations. Change was implemented by altering the herd performance and inputs of the base scenario to construct the new scenario. The comparison of the two scenarios, one of which reflected the implementation and results of the proposed change from a common starting point, was the focus of the analysis. Partial discounted cash flow (DCF) techniques were applied to calculate the marginal returns associated with additional capital or resources invested within farm operations. The DCF analysis was compiled in real (constant value) terms, with all variables expressed in terms of the price level of the present year (2017). It was assumed that future inflation would affect all costs and benefits equally. The Breedcow and Dynama herd budgeting software (Version 6.02; Holmes et al. 2017) and spreadsheetbased investment analysis tools (as described by Gittinger (1982) and Robinson and Barry (1996), and applied by Makeham and Malcolm (1993) and Campbell and Brown (2003)) were used to develop integrated herd models and discounted cashflow budgets for each alternative scenario. The spreadsheets contained livestock schedules linked to cash flow and investment budgets, for the base scenarios and each alternative scenario, for an interval of 30 years. This allowed for a marginal analysis, comparing the base scenarios with the other scenarios, to be completed.

\section{Alternative production scenarios and the criteria used to compare the scenarios}

Growth paths were developed for 22 scenarios for steers grazing buffel grass pastures with and without access to leucaena-grass pastures and/or forage oats for varying intervals from weaning 
to marketing, as defined in Table 1 . The economic criteria were marginal net present value (NPV) at the required rate of return ( $5 \%$; taken as the real opportunity cost of funds to the producer) and the internal rate of return. The marginal NPV was calculated as the net returns (income minus costs) over the life of the investment, expressed in present-day terms. The internal rate of return was calculated as the discount rate at which the present value of income equals the present value of total expenditure (capital and annual costs), i.e. the break-even discount rate. The marginal NPV was amortised at a 5\% discount rate over the life of the investment to identify the annual average improvement in profit generated by the implementation of the alternative growth path. Profit was calculated net of an allowance for the labour and management of the owner. The financial criteria were peak deficit, the number of years to the peak deficit, and the payback period in years. The beef enterprise started with no debt but accumulated debt and paid interest as required by the implementation of each growth path. Peak deficit in cash flow was calculated assuming interest was paid on the deficit and compounded for each additional year in the investment period. The payback period was calculated as the number of years taken for the cumulative present value to become positive.

\section{Representative case-study beef cattle enterprises}

The modelled enterprises were situated centrally in the Fitzroy NRM region in central Queensland, near Rolleston, with the predominant land type considered to be Brigalow softwood scrub (Whish 2011) that had been cleared of timber and developed to sown pasture in the 1970s-1980s with buffel being the predominant species, as is typical for the region (Thornton and Elledge 2013; DNRM 2017a). Bos indicus crossbred steers were grazed on buffel grass pastures and/or highquality forages from weaning (200 kg in May) until marketing as either feed-on steers (450 kg at feedlot) or finished steers (605 kg liveweight and $310 \mathrm{~kg}$ carcass weight). These two markets were selected as representative of the most common sale targets off buffel grass in the region (Bowen et al. 2015a). Feed-on steers were required to reach $474 \mathrm{~kg}$ liveweight in the paddock before sale, to allow for a loss of 5\% liveweight during transit from the paddock to the feedlot. Finished steers were required to reach $605 \mathrm{~kg}$ in the paddock before sale, to allow for the same loss of 5\% liveweight before slaughter, while assuming a dressing percentage of 54\% at slaughter (Wythes et al. 1983; McKiernan et al. 2007). The price basis for each class of livestock was derived from Roma store sale data and JBS Australia Dinmore abattoir (Ipswich, Queensland) respectively, between July 2008 and November 2015, which were taken to be representative of long-term averages. Freight costs for steers were calculated as described in Bowen et al. (2015b). A detailed description of the herd structures and dynamics, and cattlemanagement activities, treatments and cost assumptions required as inputs for the analysis are given in Bowen and Chudleigh (2017).

\section{Steer turnover enterprise}

It was assumed that the area of the property available for grazing was 1000 ha and that steers were purchased as weaners and sold at the specified market target weight. Minimal plant and equipment were required to operate the enterprise and contractors were used for all leucaena-grass and forage oats plantings, as is typical for this enterprise type and property size in central Queensland.

\section{Breeding and finishing enterprise}

The breeding and finishing enterprise was a total area of 8700 ha and was considered to have a mixture of land types, with the higher-quality Brigalow softwood scrub land type being used for growing and fattening steers and lesser-quality land types (predominantly open eucalypt woodlands) being used for the breeder herd. The beef enterprise was considered as a selfreplacing breeding and growing activity that relied on production of weaners by a $B$. indicus crossbred breeding herd. The property and herd characteristics were informed by Barbi et al. (2016) and Bowen et al. (2015b). Reproduction, mortality and culling parameters were informed by Henderson et al. (2012), McGowan et al. (2014) and Chudleigh et al. (2016). As the base property (buffel grass-only production system) undertook no farming activities, the growing of oats required purchase of additional plant and equipment suitable for the area to be grown. As is common industry practice for leucaena plantings, contractors were used to prepare the paddock and plant the forage.

\section{Pasture and animal production}

Assumptions for forage and animal growth parameters are shown in Table 2. The buffel grass pasture provided either with or without access to leucaena-grass or forage oats in the steer growth-path scenarios was considered to be in A land condition (Scale A-D; Quirk and McIvor 2003), reflecting optimal capacity of the land to produce useful forage. The buffel pasture was assigned a utilisation rate of $30 \%$ of the annual pasture biomass growth, which has been suggested as a safe pasture utilisation for this land type for long-term sustainability (Whish 2011). The GRASP pasture growth model (McKeon et al. 2000; Rickert et al. 2000) was used to simulate annual long-term, median buffel grass pasture biomass production for the location, using 100 years of historical rainfall and climate data to June 2016 and assuming $2 \mathrm{~m}^{2} /$ ha tree basal area, which is considered typical for the region ( $\mathrm{P}$. Jones, pers. comm.) and reflects timber regrowth. Perennial grass biomass production and utilisation rate in the leucaena-grass pasture was assumed to be the same as that for the buffel grass-only pastures, as per Bowen et al. (2015b). Estimates of leucaena edible biomass production and utilisation rate by cattle was derived from Dalzell et al. (2006), Elledge and Thornton (2012), Bowen et al. (2018), and regional producer demonstration sites (S. Buck, pers. comm.). The leucaena component of the diet was assumed to be 0.50 , which was the average measured proportion for cattle on commercial properties in central Queensland (Bowen et al. 2018). Forage oats was assumed to provide grazing for 83 days from 20 July. The Agricultural Production Systems Simulator (APSIM) modelling framework (McCown et al. 1996; Keating et al. 2003) was used to simulate median annual forage-biomass production for the location by using 117 years of climate data and assuming $100 \mathrm{~kg} \mathrm{~N} /$ ha as a base $\mathrm{N}$ concentration (Cox 2009). The median oats biomass production was determined for years in which the APSIM model indicated that conditions were suitable for planting an oats crop and, therefore, did not include zero 


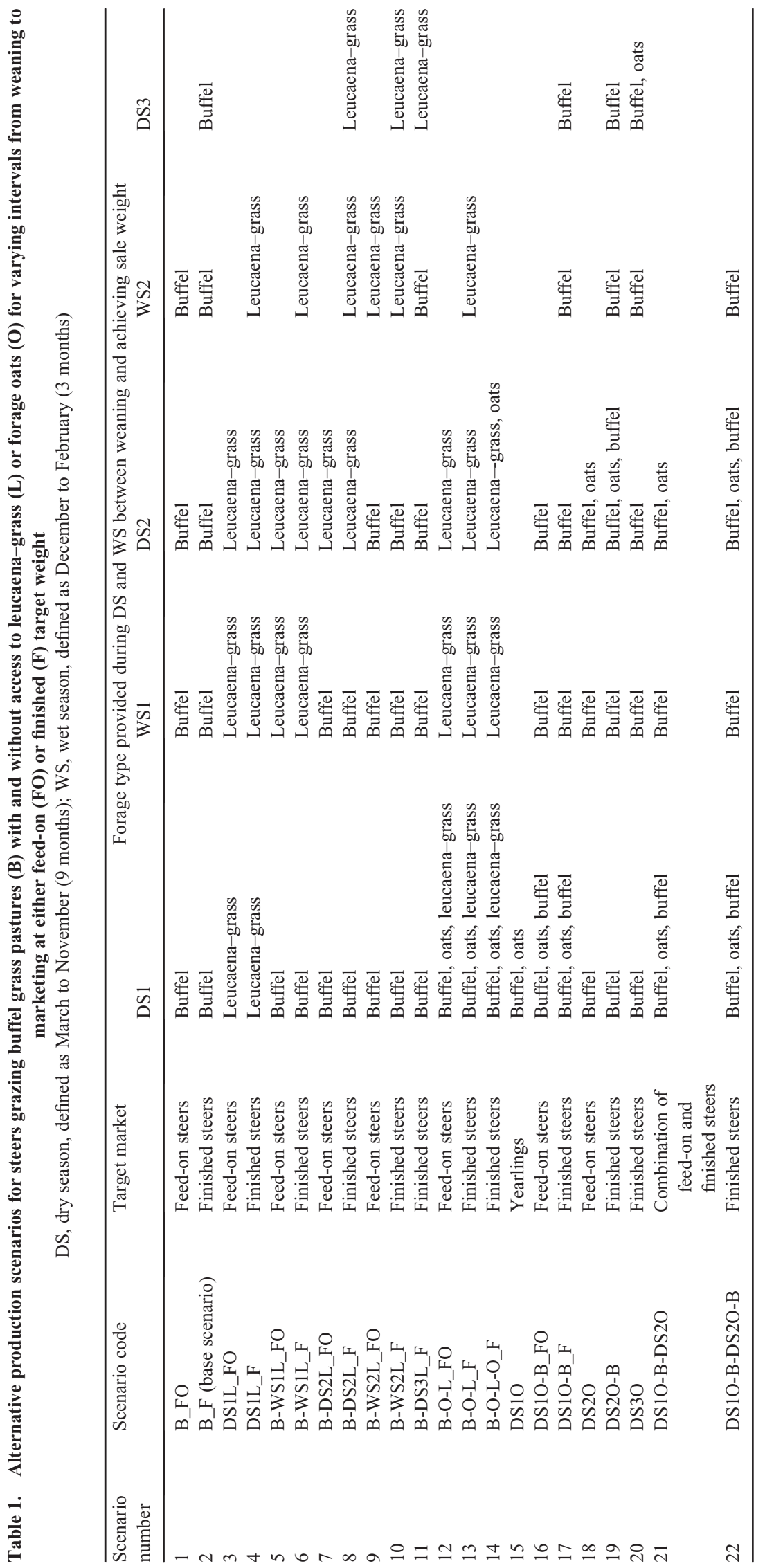


Table 2. Assumed forage and steer growth parameters for buffel grass and leucaena-grass pastures, and forage oats, growing on Brigalow softwood-scrub land type near Rolleston in central Queensland

The edible leucaena component includes leaves and stems $<5 \mathrm{~mm}$ in diameter. AE, adult equivalent, defined in terms of the forage intake of a 2.25-year-old 450-kg Bos taurus steer at maintenance, consuming a diet of the specified dry-matter digestibility (DMD) and walking $7 \mathrm{~km} /$ day (McLean and Blakeley 2014); LWG, liveweight gain

\begin{tabular}{lcrrr}
\hline Biological parameter & Buffel grass & \multicolumn{2}{c}{ Leucaena-grass } & Forage oats \\
& & Edible leucaena & Grass \\
\hline Median, annual pasture biomass production (kg DM/ha) & 5100 & 1800 & 5100 & 5432 \\
Utilisation of annual biomass growth (\%) & 30 & 85 & 30 & 30 \\
Average annual diet DMD of grazing cattle (\%) & 57 & 63 & 65 \\
Average annual steer LWG (kg/head) & 180 & 255 & 91 \\
Carrying capacity (AE/ha) & 0.47 & 1.10 & 2.73 \\
\hline
\end{tabular}

values for years in which oats was not planted. It was assumed that $30 \%$ of the annual oats biomass was utilised as per data collected for commercial properties in central Queensland (Bowen et al. 2015b).

Seasonal steer growth rates for buffel grass pasture, leucaena-grass pasture and forage oats were assigned with reference to available measured data for diet dry-matter digestibility, seasonal rainfall data and liveweight gain (QDPI 2003; Bowen et al. 2010, 2015a, 2015b). Average annual steer growth rates for each forage type are shown in Table 2. In growth-path scenarios where steers grazed a leucaena-grass or buffel grass pasture after grazing an oats crop, their growth rate was reduced by a factor of 0.25 relative to steers not fed oats over the following 140 days to allow for a compensatory growth effect of the steers not fed forage oats (Tomkins et al. 2006).

The carrying capacity (for an adult equivalent; Table 2) and stocking rate (of steers of the designated breed and age) for each scenario were calculated as the product of the median annual forage biomass production (see above) and the specified utilisation level, divided by the annual pasture consumption of the steers. The spreadsheet calculator, QuikIntake (McLennan and Poppi 2016), which is based on the Australian Feeding Standards (NRDR 2007) with some modifications for tropical cattle and diets (McLennan 2014), was used to calculate the average cattle dry-matter intakes of pasture over each 12-month period.

The area allocated to each forage type in each growth path was calculated by iteration of the number of steers to match the forage supply. For the breeding and finishing enterprise, the herd size and structure were optimised within the limits applied by property size and the respective areas and quality of forage type. The forage area allocated to each growth path in each scenario was sufficient to meet the needs of the steers for the entire grazing period and included allowance for steer age groups that overlapped (Tables 3, 4).

\section{Forage costs}

Leucaena was considered to be sown in 8-m double rows with perennial grass sown in the inter-rows. The paddock was converted from perennial grass to leucaena-grass by using a chisel plough and a tyne cultivator, twice each, to establish an appropriate seed bed over $100 \%$ of the area to be developed. Leucaena development costs at contract rates were AU\$554/ha.
Table 3. Modelled areas of forage required to implement the growth-path scenarios on the steer turnover enterprise (total grazing area 1000 ha)

Scenarios are defined in Table 1. DS, dry season, defined as March to November (9 months)

\begin{tabular}{|c|c|c|c|c|}
\hline \multirow{2}{*}{ Scenario } & \multicolumn{4}{|c|}{ Allocated area of forage (ha) } \\
\hline & Buffel & Oats - DS1 & Leucaena & Oats - DS2 \\
\hline B_FO & 1000 & & & \\
\hline B_F (base scenario) & 1000 & & & \\
\hline DS1L_FO & & & 1000 & \\
\hline DS1L_F & & & 1000 & \\
\hline B-WS1L_FO & 474 & & 526 & \\
\hline B-WS1L_F & 354 & & 646 & \\
\hline B-DS2L_FO & 617 & & 383 & \\
\hline B-DS2L_F & 497 & & 503 & \\
\hline B-WS2L_FO & 958 & & 42 & \\
\hline B-WS2L_F & 809 & & 191 & \\
\hline B-DS3L_F & 859 & & 141 & \\
\hline B-O-L_FO & 185 & 306 & 509 & \\
\hline B-O-L_F & 107 & 247 & 646 & \\
\hline B-O-L-O_F & 120 & 188 & 395 & 297 \\
\hline DS1O & 377 & 623 & & \\
\hline DS1O-B_FO & 848 & 152 & & \\
\hline DS1O-B_F & 913 & & & 87 \\
\hline DS2O & 793 & & & 207 \\
\hline DS2O-B & 870 & & & 130 \\
\hline DS3O & 877 & & & $123^{\mathrm{A}}$ \\
\hline DS1O-B-DS2O & 664 & 133 & & 202 \\
\hline DS1O-B-DS2O-B & 753 & 98 & & 149 \\
\hline
\end{tabular}

${ }^{\mathrm{A} O a t s}$ fed in DS3 (Dry season 3).

Leucaena was established by destocking the area of buffel grass pasture allocated to leucaena during the winter of the first year of the analysis. Leucaena was then planted during late summer of the second year and grazing commenced (generally) after May of the third year, although the commencement of grazing varied with the growth path applied. Leucaena maintenance costs applied every 10 years in the analysis totalled AU\$176.50/ha and comprised application of phosphorus (P) fertiliser (150 kg/ha superphosphate) and mechanical cutting to maintain productivity of the leucaena over the 30 years of the analysis.

For the steer turnover enterprise where contractors were used to plant forage oats, the total cost of planting was 
Table 4. Modelled areas of forage required to implement the steer growth paths for the breeding and finishing enterprise

Scenarios are defined in Table 1. DS, dry season, defined as March to November ( 9 months)

\begin{tabular}{|c|c|c|c|c|c|}
\hline \multirow[t]{2}{*}{ Scenario } & \multicolumn{5}{|c|}{ Allocated area of forage (ha) } \\
\hline & Buffel & Oats - DS1 & Leucaena & Oats - DS2 & $\begin{array}{c}\text { Total grazing } \\
\text { area for steers }\end{array}$ \\
\hline B_FO & 989 & & & & 989 \\
\hline B_F (base scenario) & 1327 & & & & 1327 \\
\hline$\overline{D S} 1 \mathrm{~L} \_F O$ & & & 378 & & 378 \\
\hline DS1L_F & & & 603 & & 603 \\
\hline B-WS1L_FO & 256 & & 283 & & 539 \\
\hline B-WS1L_F & 243 & & 444 & & 687 \\
\hline B-DS2L_FO & 413 & & 256 & & 670 \\
\hline B-DS2L_F & 396 & & 400 & & 796 \\
\hline B-WS2L_FO & 889 & & 39 & & 928 \\
\hline B-WS2L_F & 847 & & 201 & & 1047 \\
\hline B-DS3L_F & 1000 & & 165 & & 1165 \\
\hline B-O-L_FO & 84 & 139 & 231 & & 454 \\
\hline B-O-L_F & 78 & 129 & 472 & & 679 \\
\hline B-O-L-O_F & 82 & 129 & 272 & 204 & 687 \\
\hline DS10 & 90 & 149 & & & 239 \\
\hline DS1O-B_FO & 688 & 123 & & & 812 \\
\hline DS1O-B_F & 1103 & 105 & & & 1209 \\
\hline $\mathrm{DS} 2 \mathrm{O}$ & 665 & 173 & & & 838 \\
\hline DS2O-B & 1019 & 152 & & & 1171 \\
\hline DS3O & 1253 & & & $110^{\mathrm{A}}$ & 1363 \\
\hline DS1O-B-DS2O & 595 & 120 & & 181 & 896 \\
\hline DS1O-B-DS2O-B & 844 & 110 & & 167 & 1120 \\
\hline
\end{tabular}

${ }^{\mathrm{A}}$ Oats fed in DS3 (Dry season 3).

AU\$232.00/ha. For the breeding and finishing enterprise where the producer's own plant and equipment was used, the cost of oats planting was AU\$151.70/ha. Our analysis did not include the impact of seasonal variability (missed oats planting opportunities due to insufficient planting rainfall), although the APSIM modelling showed that, on average, only $69 \%$ of the past 117 years were suitable for planting oats at the target location. Hence, it was assumed that an oats crop would be planted and successful in every year it was applied within a growth path.

\section{Results}

\section{Modelled production outputs: steer turnover enterprise}

The growth-path scenario resulting in the greatest annual beef production per hectare for the steer turnover enterprise was DS1O, where weaner steers were grazed on oats and sold as yearlings at the end of the oats grazing period: $345 \mathrm{~kg} / \mathrm{ha}$. annum (Table 5). This scenario also resulted in the greatest number of steers per 1000 ha (1345), the least number of days grazing to achieve target weight (146) and the greatest average daily liveweight gain over the entire grazing period $(0.81 \mathrm{~kg} /$ day). The second greatest beef production was achieved from DS1L_FO, which involved grazing weaner steers on leucaena-grass until they attained feed-on weight: $183 \mathrm{~kg} / \mathrm{ha}$. annum. The least beef output for the steer turnover enterprise was produced from the scenario where weaner steers grazed buffel grass until attaining finishing weights (B_F; base scenario): $26 \mathrm{~kg} /$ ha.annum.

\section{Modelled production outputs: breeding and finishing enterprise}

For the breeding and finishing enterprise, the growth-path scenario resulting in the greatest annual beef production per hectare for the whole herd was DS1L_F, where weaner steers were grazed on leucaena until sale as finished steers, with $31 \mathrm{~kg} /$ ha.annum (Table 6). The least whole herd beef output was produced from DS1O, in which yearling steers were produced from forage oats, with $22 \mathrm{~kg} / \mathrm{ha}$.annum.

\section{Modelled economic and financial indicators: steer turnover enterprise}

The most profitable growth-path scenario for the steer turnover enterprise was where steers were grazed on leucaena from weaning until feed-on weight (DS1L_FO), with an extra profit/ annum of AU\$106508 over 30 years compared with the base scenario of finishing steers on buffel grass pasture (B_F; Table 7). Taking weaner steers through to finishing weights on leucaena (DS1L_F) was the second-most profitable growthpath scenario (an additional profit of AU\$74 076/annum), while feeding leucaena to steers from the start of their first wet season following weaning to finishing or feed-on weights (B-WS1L_F and B-WS1L_FO respectively) were the third- and fourth-most profitable growth paths respectively. Growth paths incorporating leucaena-grass, without oats, required 4-12 years to pay back the total extra costs (including opportunity costs) incurred to implement the growth path. The most profitable scenario, DS1L_FO, required an 8-year payback period. Growth paths 
Table 5. Modelled production outputs from a steer turnover enterprise for 22 forage scenarios including combinations of buffel (B), leucaena-grass (L) or oats (O), over dry (DS) and wet (WS) seasons between weaning and sale at either feed-on (FO) or finished (F) target weight

Scenarios are defined in Table 1. LWG, liveweight gain

\begin{tabular}{lcccc}
\hline Scenario & Steers/1000 ha & $\begin{array}{c}\text { Days to achieve } \\
\text { target weight }\end{array}$ & $\begin{array}{c}\text { Average LWG over total } \\
\text { grazing period (kg/day) }\end{array}$ & $\begin{array}{c}\text { Beef production } \\
\text { (kg/ha.annum) }\end{array}$ \\
\hline B_FO & 249 & 615 & 0.45 & 37 \\
B_F (base scenario) & 161 & 851 & 0.48 & 26 \\
DS1L_FO & 809 & 404 & 0.68 & 183 \\
DS1L_F & 475 & 609 & 0.67 & 107 \\
B-WS1L_FO & 542 & 497 & 0.55 & 100 \\
B-WS1L_F & 405 & 562 & 0.55 & 99 \\
B-DS2L_FO & 417 & 552 & 0.50 & 69 \\
B-DS2L_F & 335 & 686 & 0.59 & 67 \\
B-WS2L_FO & 275 & 601 & 0.46 & 42 \\
B-WS2L_F & 232 & 764 & 0.53 & 42 \\
B-DS3L_F & 199 & 819 & 0.50 & 33 \\
B-O-L_FO & 660 & 375 & 0.73 & 161 \\
B-O-L_F & 411 & 596 & 0.68 & 94 \\
B-O-L-O_F & 405 & 511 & 0.77 & 105 \\
DS1O & 1345 & 146 & 0.81 & 345 \\
DS1O-B_FO & 328 & 467 & 0.59 & 64 \\
DS1O-B_F & 188 & 718 & 0.56 & 36 \\
DS2O & 315 & 511 & 0.59 & 62 \\
DS2O-B & 197 & 718 & 0.56 & 38 \\
DS3O & 156 & 876 & 0.55 & 29 \\
DS1O-B-DS2O & 288 & 511 & 0.69 & 67 \\
DS1O-B-DS2O-B & 212 & 644 & 0.63 & 45 \\
\hline
\end{tabular}

Table 6. Modelled production outputs for the steer component of the breeding and finishing enterprise for steers fed 22 different forage scenarios including combinations of buffel (B), leucaena-grass (L) or oats (O), over dry (DS) and wet (WS) seasons between weaning and sale at either feed-on (FO) or finished (F) target weight

Scenarios are defined in Table 1. Whole herd beef production includes beef production from steers and sale of cull heifers, cows and bulls. LWG, liveweight gain

\begin{tabular}{lcccc}
\hline Scenario & $\begin{array}{c}\text { Number of weaner } \\
\text { steers entering the } \\
\text { growth path }\end{array}$ & $\begin{array}{c}\text { Days to achieve } \\
\text { target weight }\end{array}$ & $\begin{array}{c}\text { Average LWG } \\
\text { over total grazing } \\
\text { period (kg/day) }\end{array}$ & $\begin{array}{c}\text { Whole herd beef } \\
\text { production } \\
\text { (kg/ha.annum) }\end{array}$ \\
\hline B_FO & 249 & 615 & 0.45 & 24 \\
B_F (base scenario) & 219 & 851 & 0.48 & 24 \\
DS1L_FO & 307 & 404 & 0.68 & 30 \\
DS1L_F & 286 & 609 & 0.67 & 31 \\
B-WS1L_FO & 292 & 497 & 0.55 & 28 \\
B-WS1L_F & 278 & 562 & 0.55 & 30 \\
B-DS2L_FO & 279 & 552 & 0.50 & 27 \\
B-DS2L_F & 267 & 686 & 0.59 & 29 \\
B-WS2L_FO & 255 & 7601 & 0.46 & 24 \\
B-WS2L_F & 243 & 819 & 0.53 & 26 \\
B-DS3L_F & 232 & 375 & 0.50 & 25 \\
B-O-L_FO & 300 & 596 & 0.73 & 29 \\
B-O-L_F & 279 & 511 & 0.68 & 30 \\
B-O-L-O_F & 278 & 146 & 0.77 & 30 \\
DS1O & 321 & 467 & 0.81 & 22 \\
DS1O-B_FO & 266 & 0.59 & 26 \\
DS1O-B_F & 227 & 511 & 0.56 & 24 \\
DS2O & 264 & 718 & 0.59 & 26 \\
DS2O-B & 231 & 876 & 0.56 & 25 \\
DS3O & 212 & 511 & 0.55 & 24 \\
DS1O-B-DS2O & 258 & 644 & 0.69 & 27 \\
DS1O-B-DS2O-B & 237 & & 0.63 & 25 \\
\hline
\end{tabular}


Table 7. Modelled economic and financial indicators for the steer turnover enterprise for 22 forage scenarios including combinations of buffel (B), leucaena-grass (L) or oats (O), over dry (DS) and wet (WS) seasons between weaning and sale at either feed-on (FO) or finished (F) target weight Scenarios are defined in Table 1. Annualised marginal return on investment is the extra profit/annum for the investment period. The average annual returns are used in the calculation of \% improvement in the NPV compared with base, rather than marginal returns, as it is not possible for marginal returns to be used in such a calculation. IRR, internal rate of return; NPV, net present value; n/a, the value could not be calculated or was not applicable; in Columns Peak deficit, Year of peak deficit and Payback period, $n / a$ indicates that for these scenarios peak deficit was not achieved within the initial 30 years of the investment period and/or the investment does not have the capacity to repay the additional costs (including opportunity costs) within the first 30 years

\begin{tabular}{|c|c|c|c|c|c|c|c|}
\hline Scenario & $\begin{array}{l}\text { Annualised marginal } \\
\text { return on investment }\end{array}$ & $\begin{array}{l}\text { Peak deficit } \\
\text { (with interest) }\end{array}$ & $\begin{array}{c}\text { Year of peak } \\
\text { deficit }\end{array}$ & $\begin{array}{l}\text { Payback period } \\
\text { (years) }\end{array}$ & $\begin{array}{l}\text { Marginal } \\
\text { IRR (\%) }\end{array}$ & $\begin{array}{c}\% \text { improvement in } \\
\text { the NPV compared } \\
\text { with base }\end{array}$ & $\begin{array}{c}\text { \% change in beef production } \\
(\mathrm{kg} / \mathrm{ha} \text {.annum) compared } \\
\text { with base }\end{array}$ \\
\hline B_FO & AU\$2803 & $\mathrm{n} / \mathrm{a}$ & $\mathrm{n} / \mathrm{a}$ & $\mathrm{n} / \mathrm{a}$ & 1.57 & -3 & 43 \\
\hline \multicolumn{8}{|l|}{ B_F (base scenario) } \\
\hline DS1L_FO & AU\$106508 & -AU\$893 492 & 3 & 8 & 18.68 & 121 & 609 \\
\hline DS1L_F & AU\$74 076 & -AU\$1 048630 & 4 & 11 & 13.08 & 85 & 313 \\
\hline B-WS1L_FO & AU\$56 676 & -AU\$488 273 & 3 & 7 & 19.82 & 65 & 286 \\
\hline B-WS1L_F & AU\$64 578 & -AU\$719 117 & 4 & 10 & 14.90 & 74 & 282 \\
\hline B-DS2L_FO & AU\$29210 & -AU\$337287 & 3 & 9 & 13.72 & 33 & 168 \\
\hline B-DS2L_F & AU\$43927 & -AU\$541820 & 4 & 11 & 14.08 & 50 & 159 \\
\hline B-WS2L_FO & AU\$7863 & -AU\$71 411 & 3 & 4 & 70.10 & 9 & 62 \\
\hline B-WS2L_F & AU\$18361 & -AU\$211333 & 4 & 10 & 14.64 & 21 & 61 \\
\hline B-DS3L_F & AU\$7368 & -AU\$144 167 & 4 & 12 & 11.10 & 8 & 29 \\
\hline B-O-L_FO & AU\$42 412 & -AU\$696685 & 3 & 12 & 13.30 & 48 & 523 \\
\hline B-O-L_F & AU\$16419 & -AU\$911233 & 4 & 17 & 7.31 & 19 & 265 \\
\hline B-O-L-O_F & AU\$2015 & -AU\$788473 & 4 & 20 & 5.34 & 2 & 306 \\
\hline DS1O & -AU\$51 073 & $\mathrm{n} / \mathrm{a}$ & $\mathrm{n} / \mathrm{a}$ & $\mathrm{n} / \mathrm{a}$ & $\mathrm{n} / \mathrm{a}$ & -58 & 1237 \\
\hline DS1O-B_FO & $-\mathrm{AU} \$ 471$ & -AU\$117478 & 1 & 6 & 4.52 & -1 & 149 \\
\hline DS1O-B_F & -AU\$32 220 & $\mathrm{n} / \mathrm{a}$ & $\mathrm{n} / \mathrm{a}$ & $\mathrm{n} / \mathrm{a}$ & $\mathrm{n} / \mathrm{a}$ & -37 & 39 \\
\hline $\mathrm{DS} 2 \mathrm{O}$ & -AU\$9224 & $\mathrm{n} / \mathrm{a}$ & $\mathrm{n} / \mathrm{a}$ & $\mathrm{n} / \mathrm{a}$ & -7.43 & -11 & 139 \\
\hline DS2O-B & -AU\$8541 & $\mathrm{n} / \mathrm{a}$ & $\mathrm{n} / \mathrm{a}$ & $\mathrm{n} / \mathrm{a}$ & 0.24 & -10 & 45 \\
\hline $\mathrm{DS} 3 \mathrm{O}$ & -AU\$8731 & $\mathrm{n} / \mathrm{a}$ & $\mathrm{n} / \mathrm{a}$ & $\mathrm{n} / \mathrm{a}$ & -3.59 & -10 & 12 \\
\hline DS1O-B-DS2O & -AU\$38 377 & $\mathrm{n} / \mathrm{a}$ & $\mathrm{n} / \mathrm{a}$ & $\mathrm{n} / \mathrm{a}$ & -8.54 & -44 & 158 \\
\hline DS1O-B-DS2O-B & -AU\$49 194 & $\mathrm{n} / \mathrm{a}$ & $\mathrm{n} / \mathrm{a}$ & $\mathrm{n} / \mathrm{a}$ & -6.70 & -56 & 75 \\
\hline
\end{tabular}

that incorporated oats forage in addition to leucaena-grass resulted in lower profitability than did similar growth paths that incorporated only leucaena, (i.e. B-O-L_FO $<$ DS1L_FO and B$\left.\mathrm{O}-\mathrm{L} \_\mathrm{F}<\mathrm{DS} 1 \mathrm{~L} \_\mathrm{F}\right)$. The growth path providing oats forage twice, in Dry seasons 1 and 2, with leucaena-grass in between, and resulting in the youngest age of turnoff at finished weights (B-OL-O_F), was only marginally more profitable than was the base scenario, with an additional profit of AU\$2015/annum. The incorporation of forage oats into a buffel-based growth path (without leucaena) always reduced the profitability of the steer turnover enterprise compared with the base scenario of finishing steers from weaning on buffel grass pasture (B_F). The most profitable of the oats with buffel grass scenarios was that where weaner steers were fed oats in Dry season 1 and then returned to buffel grass to produce feed-on steers (DS1O-B_FO), with an annualised marginal return of -AU\$471. The other seven oats and buffel grass scenarios did not achieve peak deficit within the 30-year investment period, meaning that the investment would not have the capacity to repay the additional costs required to incorporate oats into the growth paths.

\section{Modelled economic and financial indicators: breeding and finishing enterprise}

The most profitable growth-path scenario for the breeding and finishing enterprise was that where steers were grazed on leucaena-grass from weaning until achieving feed-on weight
(DS1L_FO with purchased breeders), with an additional profit of AU\$31 383/annum over 30 years compared with the base scenario of finishing steers on buffel grass pasture (B_F; Table 8). If breeder numbers were allowed to increase naturally over time rather than maximising utilisation of the leucaena immediately, then the most profitable growth-path scenario was finishing steers on leucaena-grass from Wet season 1 (BWS1L_F), with an additional profit of AU\$17 625/annum. For all growth-path scenarios where the age of turn-off of steers was reduced (compared with the base scenario of producing finished steers from buffel grass pastures) and breeder numbers were allowed to naturally increase, the foregone income related to retaining breeders, plus the delay in matching steer weaner numbers to the increased supply of nutrition, significantly reduced the NPV (data for purchase of additional breeders are presented only for DS1L_FO). Furthermore, the Scenario DS1L_FO required a 19-year payback period with natural breeder number increase, but a 14-year payback period if additional breeders were purchased to fully utilise the additional forage supply more quickly. Growth paths that incorporated oats forage in addition to leucaena-grass resulted in a lower profitability than did similar growth paths that incorporated only leucaena (i.e. B-O-L_FO $<$ DS1L_FO and B-O-L_F $<$ DS1L_F). Furthermore, all three of the growth paths incorporating oats forage in addition to leucaena (B-O-L_FO, B-O-L_F and B-O-LO_F) resulted in a substantially lower return than did the base 
Table 8. Modelled economic and financial indicators for the breeding and finishing enterprise for steers fed 22 different forage scenarios including combinations of buffel (B), leucaena-grass (L) or oats (O), over dry (DS) and wet (WS) seasons between weaning and sale at either feed-on (FO) or finished (F) target weight

Scenarios are defined in Table 1. Annualised marginal return on investment is the extra profit/annum for the investment period. The average annual returns are used in the calculation of \% improvement in the average annual profit compared with base, rather than marginal returns, as it is not possible for marginal returns to be used in such a calculation. IRR, internal rate of return. n/a, the value could not be calculated or was not applicable; in Columns Year of peak deficit and Payback period, n/a indicates that for these scenarios peak deficit was not achieved within the initial 30 years of the investment period and/or the investment does not have the capacity to repay the additional costs (including opportunity costs) within the first 30 years

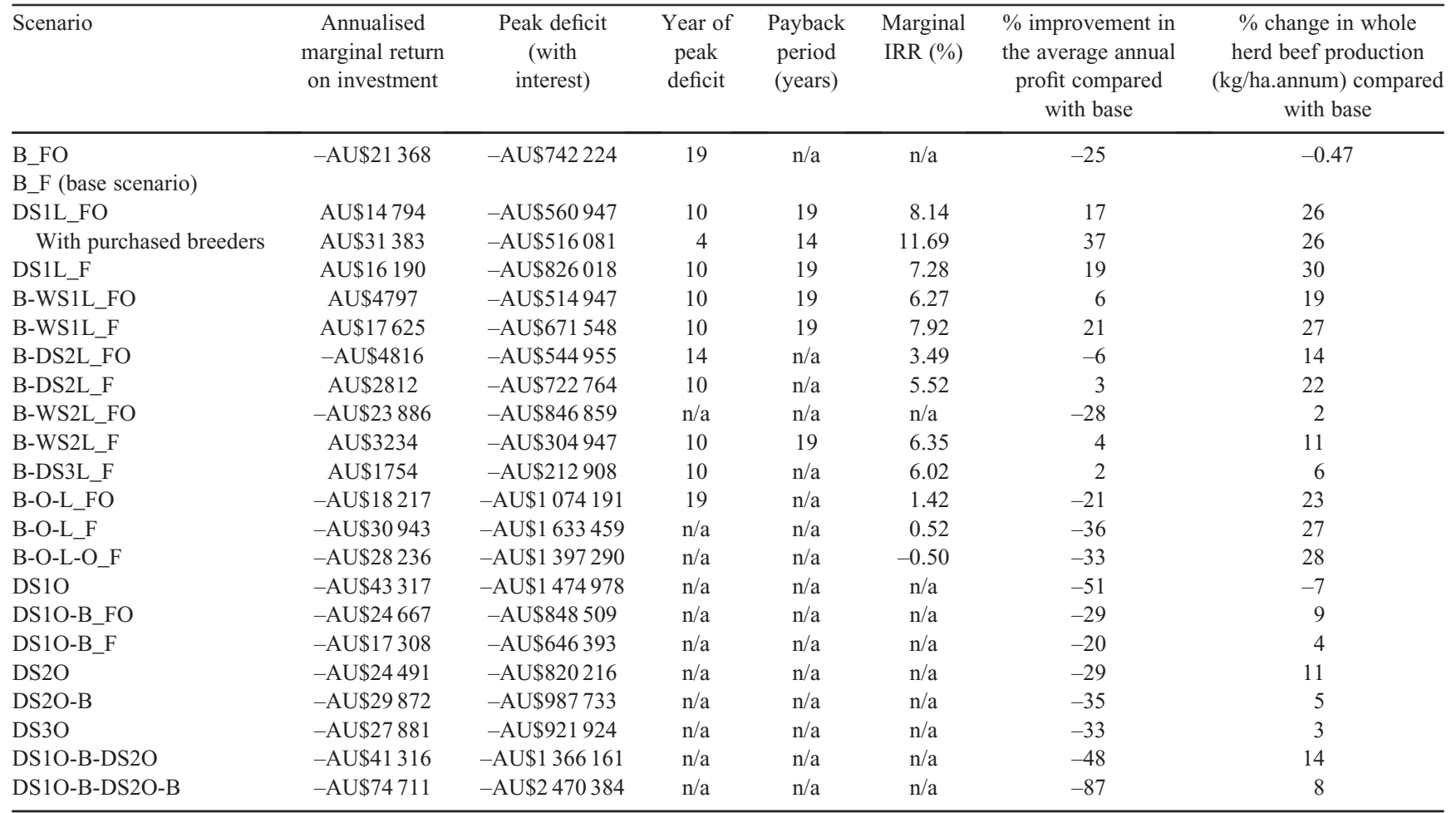

scenario of finishing steers on buffel grass pasture (B_F). The growth path providing oats forage twice, in DS1 and DS2, with leucaena-grass in between, and resulting in the youngest age of turnoff at finished weights (B-O-L-O_F), produced an annualised marginal return of $-\mathrm{AU} \$ 28236$ when compared with the base scenario (B_F). The incorporation of forage oats into a buffel grass growth path (without leucaena) always reduced the profitability of the breeding and finishing enterprise compared with the base scenario of finishing steers from weaning on buffel grass pasture (B_F). The most profitable of the oats with buffel grass scenarios was where weaner steers were fed oats in DS1 and then returned to buffel grass to produce finished steers (DS1O-B_F), with an annualised marginal return of $-\mathrm{AU} \$ 17308$. None of the eight scenarios comprising oats and buffel grass combinations achieved peak deficit within the 30-year investment period, meaning that the investment would not have the capacity to repay the additional costs required to incorporate oats into the growth paths.

\section{Relationship between production outputs and financial indicators}

As is evident from Tables 7 and 8, there were no meaningful relationships across the alternative growth-path scenarios between the change in annual profit and the amount of extra beef produced, although there was some evidence of a weak relationship between $\%$ change in annual profit and $\%$ change in total beef production $\left(r^{2}=0.32\right)$ for the breeding and finishing enterprise. Although the scenario producing the greatest $\%$ increase in beef production was among the most profitable for the breeding and finishing enterprise (DS1L_F), many of the other scenarios that produced large increases in weaner and beef production (e.g. B-O-L-O_F) resulted in a decrease in annual profit compared with the base scenario (B_F).

\section{Discussion}

The present study represents the first known attempt to assess the most profitable way of incorporating high-quality forages into the whole-of-life steer growth path on forage systems in the subtropics of Australia. In the present analysis, we have assessed the effect of the change in growth path on the overall herd structure and whole-farm profitability to provide insights to guide business investment decisions. Both the steer turnover and the breeding and finishing enterprise analyses showed that placing steers onto leucaena-grass pastures at weaning and keeping them there until they achieved a feed-on weight (DS1L_FO) was substantially more profitable than was any 
other growth path, providing that the breeder numbers were optimised. Furthermore, incorporating leucaena-grass pastures at any steer age improved the profitability of the steer turnover enterprise (AU\$7368-AU\$106508 extra profit/ annum) and similarly for the breeding and finishing enterprise (AU\$1754-AU\$31383 extra profit/annum), except for two scenarios where leucaena-grass pastures were provided to older steers targeted at the feed-on market (AU\$4816 and AU\$23 886 less profit/annum). These results are in agreement with gross margin analyses conducted for commercial properties, and whole-farm case-study analyses, where leucaena-grass systems were identified as the most profitable forage option for beef cattle production in central Queensland (Bowen et al. $2015 a, 2015 b, 2018)$. However, unlike the previous work, our current analyses have identified the most profitable way to utilise high-quality forages within the steer growth path, considering the implementation phase, the additional capital required, the economic life of the forage and the effect on herd structure. Gross margins cannot indicate whether a strategy is more or less profitable compared with other alternative investments at the farm level. Marginal DCF analysis, as used in the present study, is required to compare the net returns generated by alternative investments and to account for changes over time in labour, capital and herd structure and also to account for the opportunity cost of alternative production systems.

Despite the evident profitability of implementing a leucaena-grass system, it was associated with increased peak deficit levels and financial risk to the business, with payback periods of 8-14 years required for even the most profitable leucaena-grass growth path (DS1L_FO). This financial risk, and the long payback period, is likely one factor explaining the low exploitation of this resource in Queensland, despite the large potential area suited to leucaena plantings (Peck et al. 2011; Beutel et al. 2018). Further constraints to leucaena implementation include the difficulty and risk of establishment and the additional management expertise required to productively utilise the resource (Shelton et al. 2005; Peck et al. 2011; Bowen et al. 2015a). Furthermore, the potential productivity of existing leucaena-grass forage systems has not always been achieved due to the failure of some producers to recognise and address limitations. These include fertiliser requirements (Radrizzani et al. 2010, 2016), particularly P and sulfur, and the requirement for inoculation of cattle with the Synergistes jonesii rumen-fluid inoculum to prevent mimosine and dihydroxypyridine toxicity and associated reduction in cattle growth rates (Dalzell et al. 2012; Bowen et al. 2015b). In addition, research is required to better elucidate doseresponse relationships for $\mathrm{P}$ fertiliser and, thus, enhance economic efficiency (Peck et al. 2015).

All growth paths that incorporated forage oats and leucaenagrass, in either a steer turnover or a breeding and finishing enterprise, resulted in a lower economic and financial performance than did a similar growth path that incorporated leucaena-grass only. Furthermore, incorporation of oats into a buffel grass growth path always reduced the profitability of a steer turnover or a breeding and finishing enterprise. These findings do not indicate that beef enterprises that incorporate forage oats are unprofitable, only that they are likely to be less profitable than the alternative buffel grass-only beef enterprise. In our analysis, we did not account for the years that were likely to be unsuitable for planting oats (31\% of years), which would further reduce the profitability of the oats growth-path scenarios. The poor relative profitability of utilising oats forage was seen despite oats enabling a younger age of turn-off and despite its capacity to fill the 'feed gap' resulting from poor quality of available forage over the winter dry season. These results are also in agreement with our previous gross margin and wholefarm analyses conducted for commercial properties in central Queensland (Bowen et al. 2015a, 2015b, 2018). However, our results are in contrast to results of enterprise-scale bio-economic modelling, which indicated potentially large economic benefits from utilising small areas of irrigated annual forages, including oats, as part of beef-production systems in central Queensland and northern Australia in general (Bell et al. 2014; Hunt et al. 2014). The latter studies did not consider the implementation phase for the forage strategies or the partial return on the investment at the property level. As for beef enterprises incorporating leucaena-grass into the production system, forage oats increased the peak deficit and financial risk of the business substantially, compared with utilising buffel grass pastures for growing and finishing steers.

For the breeding and finishing enterprise, building up breeder numbers naturally over time to meet the steer needs of a growth path had a slightly higher financial risk and was substantially less profitable over the life of the investment than was purchasing additional breeders. The purchase of additional breeders increased the peak deficit in some cases, but often reduced the period of time required to pay back the total costs of implementing the growth path. Producers seeking to rapidly adopt the most profitable growth path would need to carefully plan the implementation phase to reduce the riskiness of the investment. Industry observations indicate that producers developing leucaena paddocks often adopt a staged approach to reduce both the establishment risk and financial risk.

The ranking in profitability of producing feed-on versus finished steers from the same growth path was not consistent across the various growth paths or between the steer turnover and the breeding and finishing enterprises. Several factors contributed to the relative profitability of the alternative market targets; these included the time taken to change the growth path and build up breeder and/or steer numbers, the efficiency of younger steers in converting forage to weight gain per hectare, and the premium (AU\$/kg liveweight) for feed-on steer beef compared with finished steer beef.

The price basis for each class of livestock was derived from Roma store sale data and JBS Australia Dinmore abattoir (Ipswich, Queensland) prices achieved between July 2008 and November 2015. These prices were taken to be representative of long-term averages, but there has been a considerable and sustained increase in the price paid for beef since mid-2014 (MLA 2017). Providing the price basis (relationship) among the various classes of steer does not change, the rising prices would make all options more profitable but the ranking of the growthpath scenarios would remain unchanged. However, there is some evidence that demand and prices for younger classes of steers (weaner and lighter steers) have improved more than for the finished classes of steers over recent times. On the basis of 
current steer prices, there is a very strong case for targeting the production of lightweight steers off leucaena (lighter than the feed-on scenarios examined in the present analysis). Beef enterprise managers considering targeting heavier steers off leucaena at current prices would need to incorporate the steerprice basis, relevant to their options, into their calculations at the time the decision is being made.

Our analyses clearly showed that there was no meaningful relationship between change in profit and change in productivity of the enterprise, in terms of the number of extra weaners produced or the additional beef produced per hectare. These results are in agreement with those reported by Bowen et al. (2018) for gross margin results obtained for commercial beef producers utilising a range of forage types in central Queensland, and those of Chudleigh et al. (2016) for investments to improve the productivity of the breeder herd in northern Australia. This finding reflects the principle that the most profitable level of output is achieved when marginal cost equals marginal revenue, never when production is maximised (Ferris and Malcolm 1999).

In the present study, the biological parameters required as inputs for the analysis were exogenously derived from empirical data and expert opinion of experienced scientists and extension officers, as well as by utilising outputs from plant- and animalprocess submodels where these were known to produce reliable results. No biophysical models currently exist that can predict leucaena edible biomass growth or growth of grass pasture within leucaena rows. In our study, the GRASP pasture growth model (McKeon et al. 2000; Rickert et al. 2000) and the APSIM cropping simulation model (McCown et al. 1996; Keating et al. 2003) were used to predict median forage output for buffel grass-only pastures and oats forage respectively, due to satisfactory agreement of predicted and observed data for perennial grass pastures and oats forage biomass growth in previous studies (e.g. Bowen et al. 2015b). However, as the growth models for these forage species were developed from a limited pool of datasets, the reliability of the output should be treated with caution. As measurements on commercial properties in central Queensland showed that the APSIM model was not able to adequately predict the effects of grazing (consumption and trampling) on oats biomass (Bowen et al. 2015b), the estimated consumption of all forage types, in combination with assumed utilisation rates, was used to determine forage carrying capacity in the present study. Seasonal liveweight gains were derived exogenously due to the generally poor accuracy of prediction of grazing cattle performance in the tropics and sub-tropics, primarily due to difficulties in predicting diet quality and intake of forage (McLennan and Poppi 2005; Dove et al. 2010; McLennan 2014; Bowen et al. 2015b). Given the limitations of existing dynamic, simulation models when applied to the northern Australian grazing lands and the forage types of interest in the present study, we believe our approach was the most appropriate of those presently available to represent the relevant plant and animal production responses.

In conclusion, the present study has provided valuable insights into the most profitable ways to incorporate highquality forages into whole-of-life growth paths of steers in central Queensland. Further research is required to better understand compensatory growth effects in northern cattle production systems and also effects of utilisation rates of buffel grass, and other sown grass and legume species, on plant biomass production, land condition decline, cattle diet quality and cattle production. This would allow improvement of existing modelling capabilities, which, in turn, will better inform whole-farm economic analysis.

\section{Conflicts of interest}

The authors declare no conflicts of interest.

\section{Acknowledgements}

This study was funded by the Department of Agriculture and Fisheries, Queensland. We thank Giselle Whish for conducting pasture biomass simulations using GRASP and Jo Owens for conducting oats biomass simulations using APSIM. We have benefitted from discussion and review provided by many animal and pasture scientist colleagues within Queensland Government departments.

\section{References}

ABS (Australian Bureau of Statistics) (2018) '7503.0 value of agricultural commodities produced, Australia, 2016-17.' Available at http://www. abs.gov.au/AUSSTATS/abs@.nsf/DetailsPage/7503.02016-17?Open Document [Verified November 2018]

Barbi E, Moravek T, Anderson A (2016) The 2011-14 reef catchments beef industry survey report. State of Queensland, Department of Agriculture and Fisheries, Brisbane, Qld.

Bell LW, Hayes RC, Pembleton KG, Waters CM (2014) Opportunities and challenges in Australian grasslands: pathways to achieve future sustainability and productivity imperatives. Crop and Pasture Science 65, 489-507. doi:10.1071/CP13420

Beutel TS, Tindall D, Denham R, Trevithick R, Scarth P, Abbott B, Holloway C (2014) Getting ground cover right: thresholds and baselines for a healthier reef. Report to the Reef Rescue Research and Development Program. Reef and Rainforest Research Centre Limited, Cairns, Q1d.

Beutel TS, Corbet DH, Hoffmann MB, Buck SR, Kienzle M (2018) Quantifying leucaena cultivation extent on grazing land. The Rangeland Journal 40, 31-38. doi:10.1071/RJ17085

Bowen MK, Chudleigh F (2017) 'Productivity and profitability of a range of alternative steer growth paths resulting from manipulating the pasture feed base in central Queensland.' (State of Queensland, Department of Agriculture and Fisheries: Brisbane, Qld) Available at https://futurebeef. com.au/wp-content/uploads/2018/01/Optimal-cattle-growth-pathwaysin-central-Queensland-Bowen-and-Chudleigh-2017.pdf [Verified May 2018]

Bowen MK, Chudleigh F (2018) Productivity and profitability of alternative steer growth paths resulting from accessing high quality forage systems in central Queensland: a modelling approach. In 'Proceedings of the 32nd biennial conference of the Australian Society of Animal Production', 2-4 July 2018, Wagga Wagga, NSW. (Australian Society of Animal Production: Wagga Wagga, NSW)

Bowen MK, Buck SR, Gowen R (2010) High-output forage systems for meeting beef markets: Phase 1. Project B.NBP.0496 final report. Meat and Livestock Australia, Sydney.

Bowen M, Buck S, Chudleigh F (2015a) 'Feeding forages in the Fitzroy. A guide to profitable beef production in the Fitzroy River catchment.' (State of Queensland, Department of Agriculture and Fisheries: Brisbane, Qld)

Bowen MK, Chudleigh F, Buck S, Hopkins K, Brider J (2015b) Highoutput forage systems for meeting beef markets: Phase 2. Project B. NBP.0636 final report. Meat and Livestock Australia, Sydney.

Bowen MK, Chudleigh F, Buck S, Hopkins K (2018) Productivity and profitability of forage options for beef production in the subtropics 
of northern Australia. Animal Production Science 58, 332-342. doi:10.1071/AN16180

Buck S (2017) 'Pasture dieback: past activities and current situation across Queensland. Agric.-science Queensland innovation opportunity.' (State of Queensland, Department of Agriculture and Fisheries: Brisbane, Qld)

Campbell HF, Brown RP (2003) 'Benefit-cost analysis. Financial and economic appraisal using spreadsheets.' (Cambridge University Press: Cambridge, UK)

Chudleigh F, Oxley T, Cowley T, McGrath T, Moravek T, Sullivan M (2016) The impact of changing breeder herd management and reproductive efficiency on beef enterprise performance. Project B.NBP.0763 final report. Meat and Livestock Australia, Sydney.

Corbet D, Beutel T, Buck S (2016) A novel way to measure leucaena coverage in the Fitzroy. In 'Proceedings of the Northern Beef research update conference', Rockhampton, Qld, 15-18 August 2016. p. 208. (North Australia Beef Research Council: Gympie, Qld)

Cox H (2009) 'The nitrogen book. Principles of soil nitrogen fertility management in central Queensland farming systems.' (The State of Queensland, Employment, Economic Development and Innovation: Brisbane, Qld)

Dalzell S, Shelton M, Mullen B, Larsen P, McLaughlin K (2006) 'Leucaena. A guide to establishment and management.' (Meat and Livestock Australia: Sydney)

Dalzell SA, Burnett DJ, Dowsett JE, Forbes VE, Shelton HM (2012) Prevalence of mimosine and DHP toxicity in cattle grazing Leucaena leucocephala pastures in Queensland, Australia. Animal Production Science 52, 365-372. doi:10.1071/AN11236

Queensland Government, Department of Natural Resources and Mines (DNRM) (2010) 'Queensland spatial catalogue - QSpatial. Grazing land management land types, Fitzroy.' Available at http://qldspatial. information.qld.gov.au/catalogue/custom/search.page?q=\%22Grazing $\% 201$ and $\% 20$ management $\% 20$ land $\% 20$ types $\% 20-\% 20$ Fitzroy $\% 22$ [Verified February 2018]

Queensland Government, Department of Natural Resources and Mines (DNRM) (2017a) 'QImagery.' Available at https://qimagery. information.qld.gov.au/ [Verified May 2017]

Queensland Government, Department of Natural Resources and Mines (DNRM) (2017b) 'Queensland spatial catalogue - QSpatial. Land use mapping: 1999 to current, Queensland.' Available at http://qldspatial. information.qld.gov.au/catalogue/custom/search.page? $\mathrm{q}=\% 22 \mathrm{Land} \%$ 20use \%20mapping\%20-\%201999\%20to\%20Current\%20-\%20Queens land $\% 22$ [Verified February 2018]

Dove H, McLennan SR, Poppi DP (2010) Application of nutrient requirement schemes to grazing animals. In 'Proceedings of the 4th grazing livestock nutrition conference', 9-10 July 2010, Estes Park, USA. (Eds BW Hess, T Delcurto, JGP Bowman, RC Waterman) pp. 133-149. (Western Section American Society of Animal Science: Champaign, IL)

Elledge A, Thornton C (2012) The Brigalow Catchment Study: Comparison of soil fertility, forage quality and beef production from buffel grass vs. leucaena-buffel grass pastures. In 'Proceedings of the 5th joint Australian and New Zealand soil science conference: soil solutions for diverse landscapes', 2-7 December 2012. (Eds LL Burkitt, LA Sparrow) pp. 181-184. (Australian Society of Soil Science Inc.: Massey University, New Zealand)

Ferris A, Malcolm B (1999) Sense and nonsense in dairy farm management economic analysis. In 'Proceedings of the annual conference of Australian Agricultural and Resource Economics Society'. (Australian Agricultural and Resource Economics Society: Sydney) Available at http://ageconsearch.umn.edu/bitstream/123803/2/FerrisMalcolm.pdf [Verified May 2018]

Gittinger JP (1982) 'Economic analysis of agricultural projects. EDI series in economic development.' (The Economic Development Institute of the World Bank, John Hopkins University Press: Baltimore, MD)
Henderson A, Perkins N, Banney S (2012) Determining property level rates of breeder cow mortality in northern Australia. Project B.NBP.0664 final report. Meat and Livestock Australia, Sydney.

Holmes WE, Chudleigh F, Simpson G (2017) 'Breedcow and Dynama herd budgeting software package. A manual of budgeting procedures for extensive beef herds.' (State of Queensland, Department of Agriculture and Fisheries: Brisbane, Qld) Available at https://www.daf.qld.gov.au/ animal-industries/beef/breedcow-and-dynama-software [Verified May 2017]

Hunt L, Ash A, MacLeod ND, McDonald CK, Scanlon J, Bell LW, Cowley R, Watson I, McIvor J (2014) Research opportunities for sustainable productivity improvement in the northern beef industry: a scoping study. Project B.BSC.0107 final report. Meat and Livestock Australia, Sydney.

Keating BA, Carberry PS, Hammer GL, Probert ME, Robertson MJ, Holzworth D, Huth NI, Hargreaves JNG, Meinke H, Hochman Z, McLean G, Verburg K, Snow V, Dimes JP, Silburn M, Wang E, Brown S, Bristow KL, Asseng $\mathrm{S}$, Chapman S, McCown RL, Freebairn DM, Smith CJ (2003) An overview of APSIM, a model designed or farming systems simulation. European Journal of Agronomy 18, 267-288. doi:10.1016/S1161-0301(02)00108-9

Makeham JP, Malcolm LR (1993) 'The farming game now.' (Cambridge University Press: Cambridge, UK)

Malcolm B (2000) Farm management economic analysis: a few disciplines, a few perspectives, a few figurings, a few futures. In 'Proceedings of the annual conference of Australian Agricultural and Resource Economics Society'. (Australian Agricultural and Resource Economics Society: Sydney) Available at https://ageconsearch.umn.edu/bitstream/ 171920/2/malcolm.pdf [Verified May 2018]

McCown RL, Hammer GL, Hargreaves JNG, Holzworth DP, Freebairn DM (1996) APSIM: a novel software system for model development, model testing and simulation in agricultural systems research. Agricultural Systems 50, 255-271. doi:10.1016/0308-521X(94)00055-V

McGowan M, McCosker K, Fordyce G, Smith D, O'Rourke P, Perkins N, Barnes T, Marquart L, Morton J, Newsome T, Menzies D, Burns B, Jephcott S (2014) Northern Australian beef fertility project: CashCow. Project B.NBP.0382 final report. Meat and Livestock Australia, Sydney.

McKeon GM, Ash AJ, Hall WB, Stafford-Smith M (2000) Simulation of grazing strategies for beef production in north-east Queensland. In 'Applications of seasonal climate forecasting in agricultural and natural systems: the Australian experience'. (Eds G Hammer, N Nichols, C Mitchell) pp. 227-252. (Kluwer Academic Press: Dordrecht, The Netherlands)

McKiernan B, Gaden B, Sundstrom B (2007) 'Dressing percentages for cattle. Primefact 340.' (State of New South Wales, Department of Primary Industries: Sydney) Available at http://www.dpi.nsw.gov.au/ __data/assets/pdf_file/0006/103992/dressing-percentages-for-cattle.pdf [Verified May 2017]

McLean I, Blakeley S (2014) Animal equivalent methodology. A methodology to accurately and consistently calculate cattle grazing loads in northern Australia. Project B.NBP.0779 final report. Meat and Livestock Australia, Sydney.

McLennan SR (2014) Optimising growth paths of beef cattle in northern Australia for increased profitability. Project B.NBP.0391 final report. Meat and Livestock Australia, Sydney.

McLennan SR, Poppi DP (2005) Improved prediction of the performance of cattle in the tropics. Project NBP.331 final report. Meat and Livestock Australia, Sydney.

McLennan SR, Poppi DP (2016) 'QuikIntake version 5 spreadsheet calculator.' (State of Queensland, Department of Agriculture and Fisheries: Brisbane, Qld)

MLA (Meat and Livestock Australia) (2017) Market reports and prices. Available at https://www.mla.com.au/prices-markets/Market-reportsprices/ [Verified June 2017] 
NRDR (2007) 'Nutrient requirements of domesticated ruminants.' (CSIRO Publishing: Melbourne)

Peck GA, Buck SR, Hoffman A, Holloway C, Johnson B, Lawrence DN, Paton CJ (2011) Review of productivity decline in sown grass pastures. Project B.NBP.0624 final report. Meat and Livestock Australia, Sydney.

Peck G, Chudleigh F, Guppy C, Johnson B, Lawrence D (2015) Use of phosphorus fertiliser for increased productivity of legume-based sown pastures in the Brigalow Belt region: a review. Project B.NBP.0769 final report. Meat and Livestock Australia, Sydney.

Peck G, Buck S, Johnson B, O'Reagain J (2017) Improving productivity of rundown sown grass pastures. Vol. 1: project overview, key findings and recommendations. Project B.NBP.0639 final report. Meat and Livestock Australia, Sydney.

Queensland Department of Primary Industries (QDPI) (2003) 'Rainman StreamFlow V 4.3.' (Department of Agriculture, Fisheries and Forestry: Brisbane Qld) Available at https://www.daf.qld.gov.au/plants/fieldcrops-and-pastures/broadacre-field-crops/cropping-efficiency/rainman/ download [Verified May 2017]

Quirk M, McIvor J (2003) 'Grazing land management: technical manual.' (Meat and Livestock Australia: Sydney)

Radrizzani A, Dalzell SA, Kravchuk O, Shelton HM (2010) A grazier survey of the long-term productivity of leucaena (Leucaena leucocephala)grass pastures in Queensland. Animal Production Science 50, 105-113. doi:10.1071/AN09040

Radrizzani A, Shelton HM, Kravchuk O, Dalzell SA (2016) Survey of longterm productivity and nutritional status of Leucaena leucocephala-grass pastures in subtropical Queensland. Animal Production Science 56, 2064-2073. doi:10.1071/AN15084

Rickert KG, Stuth JW, McKeon GM (2000) Modelling pasture and animal production. In 'Field and laboratory methods for grassland and animal production research'. (Eds L 't Mannetje, RM Jones) pp. 29-66. (CABI Publishing: New York)

Robinson LJ, Barry PJ (1996) 'Present value models and investment analysis.' (The Academic Page: Northport, AL)
Shelton HM, Franzel S, Peters M (2005) Adoption of tropical legume technology around the world: analysis of success. Tropical Grasslands 39, 198-209.

Spiegel N (2016) 'Developing an RD\&E project to address loss of productivity in Queensland pastures invaded by Indian couch (Bothriochloa pertusa).' (State of Queensland, Department of Agriculture and Fisheries: Brisbane, Qld)

Thornton C, Elledge A (2013) Runoff nitrogen, phosphorus and sediment generation rates from pasture legumes: an enhancement to reef catchment modelling. Project RRRD009 report to Reef Rescue Water Quality Research and Development Program. Reef and Rainforest Research Centre Limited, Cairns, Qld.

Tomkins NW, Harper GS, Bruce HL, Hunter RA (2006) Effect of different post-weaning growth paths on long-term weight gain, carcass characteristics and eating quality of beef cattle. Australian Journal of Experimental Agriculture 46, 1571-1578. doi:10.1071/ EA05227

Whish G (2011) 'Land types of Queensland. Version 2.0.' Prepared by the Grazing Land Management Workshop Team, PRO7-3212. (Department of Employment, Economic Development and Innovation: Brisbane, Qld) Available at http://www.futurebeef.com.au/knowledge-centre/ land-types-of-queensland/ [Verified May 2017]

Wythes JR, Brown MJ, Shorthose WR, Clarke MR (1983) Effect of method of sale and various water regimens at saleyards on the liveweight, carcass traits and muscle properties of cattle. Australian Journal of Experimental Agriculture and Animal Husbandry 23, 234-242.

Yin RK (1994) 'Case study research: design and methods.' 2nd edn. (Sage Publications: Thousand Oaks, CA)

Handling editor: Simon Quigley 